\title{
Experiment on Reuse of Effluent in Casting and Curing of Concrete
}

\author{
Mayuresh S. Bajbalkar, Rushikesh Bangar, Pratik Pawar, Rahul S. Chaudhari
}

\begin{abstract}
Due to climate change and increasing population demand of water is increasing. In coming days there will be less availability of water for construction industry. On the other hand a huge quantity of water has been released to the nearby stream after treatment from Sewage Treatment Plant by the Municipal Corporations. Reuse of waste water is very less. The waste water collected is mainly from domestic. After secondary or tertiary treatment the water is released. So it is possible to reuse the effluent water for construction (mainly for Concrete casting \& curing.

As per the literature survey, new combinations are created seven different possibilities to find which the best preferable combination to reuse the water is. This will leads to saving the portable water and also the water can be used for drinking purpose which is current need of the society. This will satisfy need of industry, society \& environment.

Main focus of this experimental investigation to search possibility to use effluent water for construction purpose individually or in combination mainly for Concrete casting \& Curing.
\end{abstract}

Keywords: Concrete, Curing, Reuse of Waste Water.

\section{INTRODUCTION}

Concrete is the main construction material used on construction industry. According to IS 456:2000, water used for preparation of concrete shall be portable water. But due to increase of demand of water for drink inking purpose municipal corporations Like Bengaluru, Chennai (The BUSINESS INSIDER, published on June 28, 2019, 18:11 IST, The TIMES OF INDIA, on May 21 2019, 7:42 IST) are not in position to supply required amount of portable water to construction work which mainly include casting and curing of concrete. In this regard. If the STP treated water (Treated Waste Water) is used result in up to $68 \%$ reductions in the cost of water required for the construction of base layers. (According to Farid H. Abed, Ph.D., ASCE; Munir D. Nazzal, Ph.D.; Mousa F. Attom, Ph.D, C ASCE, 2018). When portable water is used for curing Compressive strength was observed as $18.92 \mathrm{Mpa}$ at the age of 7 days and when STP Treated water is used it was $24.41 \mathrm{MPa}$.

Revised Manuscript Received on March 11, 2020.

* Correspondence Author

Mr. Mayuresh S. Bajbalkar*, Final year Civil Engineering student, Pimpri Chinchwad College of Engineering, Nigdi, Pune.

Mr. Rushikesh R. Bangar, Final year Civil Engineering student, Pimpri Chinchwad College of Engineering, Nigdi, Pune.

Mr. Pratik D. Pawar, Final year Civil Engineering student, Pimpri Chinchwad College of Engineering, Nigdi, Pune.

Mr. Rahul S. Chaudhari, Assistant Professor, Civil Engineering Department, Pimpri Chinchwad College of Engineering, Nigdi, Pune.

(C) The Authors. Published by Blue Eyes Intelligence Engineering and Sciences Publication (BEIESP). This is an open access article under the CC BY-NC-ND license (http://creativecommons.org/licenses/by-nc-nd/4.0/)
(Ms.Spoorthy B C, Ms.Bhavana P V, Ms.Sanjana N N, Ms.Suchitra S S). When treated effluent is used in concrete, of Grade M-30 \& M35, it was observed that there is increase in compressive strength is 3.6 and $9 \%$ respectively(Ooi Soon Lee, Mohd Razman Salim, Mohammad Ismail, MD.Imtiaj Ali, January 2017)

]

\section{TESTING OF MATERIAL}

\section{A. Cement}

For this study OPC (Ordinary Portland Cement) is used which is purchased from the local market and Aditya Birla make (53grade). The test like 1.Initial setting time 2.Final Setting time3.Soundness of cement was carried out on the cement. The results obtained are satisfying guidelines given by Indian Standard. IS 4031 (part 5\&269), IS 5513

\section{B. Coarse and Fine Aggregates}

Test on Course and Fine aggregate was carried out. Those test include, 1.Moisture content 2.Water Absorption 3.Specific Gravity 4.Fineness Modulus. The procedure followed is according to IS 2386 (part 3), IS 2386 (part III), IS 383, IS 2386-1963.

The results obtained are within the permissible limits specified in the above IS.

\section{Test on Water Samples collected.}

For this experimental study, water sample was collected from two Sewage Treatment Plants (STP) where sewage from domestic area was collected and treated. It is very important to know the characteristics of the STP Treated water before using the effluent in concrete preparation. So following tests was carried out in the laboratory to know the properties of the treated waste water.

\begin{tabular}{c|cc}
\hline Temperature & $\mathrm{pH}$ & Turbidity \\
\hline Total Solids & TDS & TSS \\
\hline TVS & TFS & Alkalinity \\
Chlorides & Hygiene Test & \\
\hline
\end{tabular}

After tests it was observed that all parameters are within range as per IS 456:2000

\section{Mixing Water}

Effluent is used for mixing and curing of concrete of M-20 proportion. 


\section{Experiment on Reuse of Effluent in Casting and Curing of Concrete}

For this seven various combinations are created so that best probable solution.

\section{E. Combinations Created}

As per the literature survey, following important points were observed,

1. Six different combinations were created (H. Saricimen, M. Shameem, M. Barry, and M. Ibrahim) by using $8 \%$ cement, Silica Fume and cement contain $8 \%$ silica fume, Portable and Treated water. After testing it was observed that about $28 \%$ increase in strength.

2. To study the Effect of Waste Water Type on Concrete Properties work was carried out (Nabil M.A. Al-Joulani) and found that compressive strength of mortar using tap water and Treated Waste Water was 140.30 \& 137.30 $\mathrm{Kg} / \mathrm{cm}^{2}$.

3. Experimental investigation was carried out to study Use of Sewage Treated Water in Concrete (Sachin Mane, Shaikh Faizal, Gyan Prakash, Shamli Bhandarkar,Vikki Kumar). For M-20 grade concrete the Compressive strength was observed as 49.20(using Treated Sewage water) and 38.37 using Tap Water respectively.

So, following seven combinations are created to study the effect of effluent in casting and curing of concrete in the proposed work.

Table No: 1 Combinations Created for Testing

\begin{tabular}{|c|c|c|c|c|}
\hline Sr. No. & Casting & Curing & \multicolumn{3}{|c|}{$\begin{array}{l}\text { NO. of Cubes For } \\
\text { Compression Test }\end{array}$} \\
\cline { 3 - 5 } & & & 7 Days & 28 Days \\
\hline 1 & P & P & 3 & 3 \\
\hline 2 & P & D1 & 3 & 3 \\
\hline 3 & P & D2 & 3 & 3 \\
\hline 4 & D1 & P & 3 & 3 \\
\hline 5 & D2 & P & 3 & 3 \\
\hline 6 & D1 & D1 & 3 & 3 \\
\hline 7 & D2 & D2 & 3 & 3 \\
\hline & Total & & 21 & 21 \\
\hline & Gross & & 42 \\
\hline
\end{tabular}

Where,

Pure Water $=\mathrm{P} \quad \& \quad$ Domestic Effluent $=\mathrm{D} 1, \mathrm{D} 2$

\section{EXPERIMENTAL PROGRAM}

\subsection{Preparation of Mix Design preparation of Combinations}

Concrete mix design was prepared for calculating the individual weight of the ingredients of the concrete. For this (Table 1, IS $10262 \mathrm{Cl} 3.2 .1 .2$, A-3 \& B-3), (Table 2, IS $10262 \mathrm{Cl} 4.2$, A-5, B-5), (Table 3, IS 10262:2009) was used.

To prepare the sample mix, first dry mixture was prepared.
Then required amount of water is added. This process consume approximately 5 minute. After mixing, slump cone test was carried out and slump found in the permissible range. For filling cubes, IS procedure is adopted. Those cubes were demolded in the next day (after 24 hours) and cured at room temperature for 7728 days.

The Mix proportions are as under,

Table 1: Mix proportion and water/cement (w/c) ratios for concrete mixtures. Mix proportions $\left(\mathrm{kg} / \mathrm{m}^{3}\right)$

\begin{tabular}{|c|c|c|c|c|}
\hline Cement & FA & CA & Water & $\begin{array}{c}\text { Water Cement } \\
\text { Ratio }\end{array}$ \\
\hline 360.426 & 724.754 & 1223.635 & 178.382 & 0.45 \\
\hline
\end{tabular}

To find load taken by the cubes so as to know the compressive strength, Forty two cubes of size $(150 \mathrm{~mm} x$ $150 \mathrm{~mm} \times 150 \mathrm{~mm}$ ) were casted. (21 cubes are required to test on 7 days and 21 at the age of 28 days). The Cubes are casted as per the guidelines given in IS: 10086-1982.

\subsection{Testing Procedure}

After curing, for 7 \& 28 days, $2000 \mathrm{KN}$ Compressive Testing Machine was used to know the load taken by individual cube. Then load was converted to compressive strength (IS: 10086-1982).

\section{TEST RESULTS FOR 7 \& 28 DAYS}

4.1 The cubes were casted at was tested at the age of 7 days and 28 days respectively. Total 21 Cubes were tested at the age of 7 days and again 21 cubes were tested at the age of 28 days.

Following table shows details of average compressive strength obtained.

Table 2: Average strength of concrete at 7 days of curing with various wastewater replacement.

\begin{tabular}{|c|c|c|c|}
\hline \multirow{2}{*}{$\begin{array}{l}\text { Sr. } \\
\text { No. }\end{array}$} & Casting & Curing & $\begin{array}{c}\text { Strength Obtained in } \\
\text { MPa }\end{array}$ \\
\cline { 2 - 3 } & \multicolumn{2}{|c|}{ Combinations } & \multicolumn{2}{|c|}{} \\
\hline 1 & P & P & 24.10 \\
\hline 2 & P & D1 & 23.60 \\
\hline 3 & P & D2 & 25.00 \\
\hline 4 & D1 & P & 22.10 \\
\hline 5 & D2 & P & 21.60 \\
\hline 6 & D1 & D1 & 22.90 \\
\hline 7 & D2 & D2 & 22.90 \\
\hline
\end{tabular}

Following graph represents the variation in strength for 7 days for various combinations.

Published By: 
Graph 1: Representation in variation in strength at the age of 7 Days.

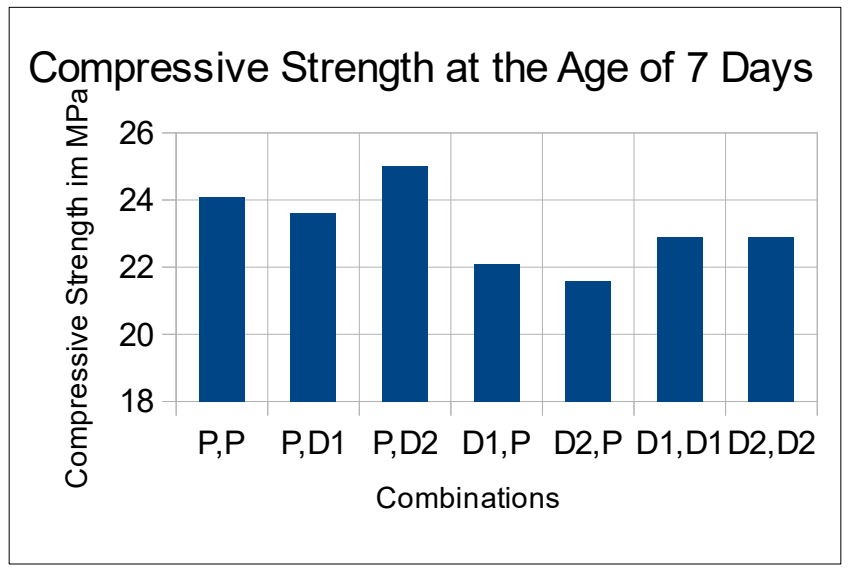

Table 3: Average strength of concrete cubes at the age of 28 days with various combinations.

\begin{tabular}{|c|c|c|c|}
\hline \multirow{2}{*}{$\begin{array}{l}\text { Sr. } \\
\text { No. }\end{array}$} & Casting & Curing & Strength Obtained in MPa \\
\cline { 2 - 3 } & \multicolumn{2}{|c|}{ Combinations } & \multicolumn{2}{|c|}{} \\
\hline 1 & P & P & 31.89 \\
\hline 2 & P & D1 & 32.38 \\
\hline 3 & P & D2 & 34.79 \\
\hline 4 & D1 & P & 32.04 \\
\hline 5 & D2 & P & 31.82 \\
\hline 6 & D1 & D1 & 30.96 \\
\hline 7 & D2 & D2 & 33.94 \\
\hline
\end{tabular}

Following graph represents the variation in strength for 28 days for various combinations.

Graph 2: Representation in variation in strength at the age of 28 Days.

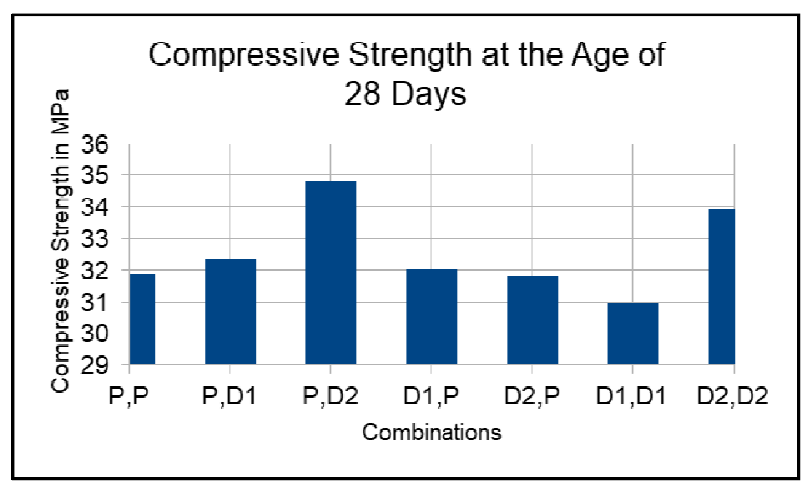

\subsection{Comparison of the results obtained}

As per the discussion above, the Average compressive strength was calculated for individual combination.
Following Graph represents the comparison between both the results obtained.

Graph 3: Representation in variation in Compressive strength at the age of $7 \& 28$ days.



\section{CONCLUSION}

After this study, following points were concluded,

1. The water samples from both the STP were satisfying the criteria mentioned in IS Code as the values obtained for the 11 tests were in the limit.

2. It was observed that nearly $24 \%, 27 \%$, and $28 \%$ in increase in the strength for PP, PD1 \& PD2 combinations respectively as compared to 7 days strength.

3. Again $31 \%, 32 \%, 26 \%, 32 \%$ of increase in compressive strength was observed for D1P, D2P, D1D1, D2D2 combination respectively as compared to 7 days strength.

4. Maximum variation was observed for D2D2 combination as casting and curing was done with the second sample.

\section{ACKNOWLEDGMENT}

The authors are thankful to Civil Engineering Department from Pimpri Chichwad College of Engineering for their valuable guidance and support.

\section{REFERENCES}

1. Mohd Razman Salim, MD.Imtiaj Ali, "Reusing treated effluent in concrete technology", University Teknologi, Malaysia, 2001.

2. Mohammad Shekarchi, Mahdi Yazdian and Naser Mehrdadi, "Use of biologically treated domestic waste water in concrete", Kuwait J.Sci.Eng.39(2B), 2012,Page No. 97-111

3. Ainul Haezah Noruzman, Bala Mohammad, Mohammad Ismail, Zaiton Abdul-Majid, "Characteristics of treated effluent and their potential applications for producing concrete", Journal of Environmental Management,2012,Page No. - 27-32.

4. Devendra Swami, Kaustav Sarkar and Bishwajit Bhattacharjee, "Use of treated domestic effluent as mixing water for concrete: effect on strength and water penetration at 28 days" The Indian Concrete Journal, Dec. 2015, Vol 89.

5. Vijay H, "Reusing Treated Effluent for Making Concrete", Journal Teknologi, International Journal of Ltest Technology in Engineering, Management and applied Science, June 2001,ISSN 2278-2540,Page No. - 21 -29.

6. Marcia Silva \& Tarun R. Naik, "Sustainable use of resourcesrecycling of sewage treatment






\section{Experiment on Reuse of Effluent in Casting and Curing of Concrete}

plan water in concrete", University of Wisconsin-Milwaukee, USA, 2015.

7. Ms.Spoorthy B C, Ms.Bhavana P V, Ms.Sanjana N N, Ms.Suchitra S S, "Determination of harden properties of concrete using STP treated water and untreated wash water", Adichuchanagiri Institute of Technology, Chikkmagaluru.

8. By Joo-Hwa Tay and Woon-Kwong Yip," USE OF RECLAIMED WASTEWATER FOR CONCRETE MIXING, Journal of Environmental Engineering, October, 1987, ISSN 0733-9372/87/00051156, Paper No. 21914.

9. K. S. AL-JABRI, A. H. AL-SAIDY, R. TAHA and A. J. ALKEMYANI, "Effect of using Wastewater on the Properties of High Strength Concrete", Published by Elsevier

10. Sachin Mane, Shaikh Faizal, Gyan Prakash, Shamli Bhandarkar, Vikki Kumar," Use of Sewage Treated Water in Concrete",International Journal of Research in Engineering, Science and Management, June2019, ISSN (Online): 2581-5792,Page No. 210-213.

11. Vinut Kulkarni1 Suresh G Patil2,"A Study on Compressive Strength of Concrete Using Treated Domestic Waste Water", IJSRD - International Journal for Scientific Research \& Development, Issue 10, 2014, ISSN (online): 2321-0613, Page No. - 680-690

12. OOI SOON LEE, MOHD RAZMAN SALIM, MOHAMMAD ISMAIL \& MD. IMTIAJ ALI,"REUSING TREATED EFFLUENT IN CONCRETE TECHNOLOGY", Journal Teknologi, Jun 2001: 1-10

13. Ramkar A.P., Ansari U.S., "Effect of Treated Waste Water on Strength of Concrete", IOSR Journal of Mechanical and Civil Engineering, Nov. Dec. 2016, e-ISSN: 2278-1684, p-ISSN: 2320-334X, Page No. - 41-45.

14. Vinut Kulkarni, Suresh G Patil, Shivasharanappa,"STUDY ON COMPRESSIVE STRENGTH OF CONCRETE BY USING TREATED DOMESTIC WASTE WATER AS MIXING AND CURING OF CONCRETE",IJRET: International Journal of Research in Engineering and Technology, Dec-2014,eISSN: 2319-1163 | pISSN: 2321-7308,Page No. - 152-156.

15. Miss. Kirtimala Laxman Narkhede, Mr. F. I. Chavan, "EFFECT OF TREATED WASTE WATER ON STRENGTH OF CONCRETE", International journal of advanced technology in Engineering and Science, June 2017, ISSN: 2348-7550, Page No. - 563-570.

16. Mr. Asif Rashid Shaikh, Dr. V. M. Inamdar," Study of Utilization of Waste Water in Concrete", IOSR Journal of Mechanical and Civil Engineering, Jul. - Aug. 2016, e-ISSN: 2278-1684,p-ISSN: 2320334X,Page No. - 105-108.

17. P. RAMA MOHAN RAO, S. M. K. MOINUDDIN and P. JAGADEESH," EFFECT OF TREATED WASTE WATER ON THE PROPERTIES OF HARDENED CONCRETE", Int. J. Chem. Sci.: 12(1), 2014, ISSN 0972-768X, Page No. 155-162.

18. Nabil M.A. Al-Joulani," Effect of Using Tertiary Treated Wastewater from Nablus Wastewater Treatment Plant (NWWTP), On Some Properties of Concrete", International Journal of Innovative Technology and Exploring Engineering (IJITEE), September 2019, ISSN: 22783075, Page No. 2460-2466.

19. HUMMAIRA KANWAL,SABAHAT ARIF, MUHAMMAD AFZAL JAVED,AMIR FAROOQ AND MUHAMMAD ARIF KHAN, "Effect on Compressive Strength of Concrete Using Treated Waste Water for Mixing and Curing of Concrete", Mehran University Research Journal of Engineering \& Technology, April 2018,p-ISSN: 0254-7821,e-ISSN: 2413-7219,Page No. 445-452.

20. Mr. Manjunatha M, Mr. Dhanraj M R, "An Experimental Study on Reuse of Treated Waste Water in Concrete - A Sustainable Approach", International Journal of Latest Engineering Research and Applications (IJLERA), July - 2017, ISSN: 2455-7137, Page No. 124-132.

21. K. Nirmalkumar and V. S ivkumar (2008), "Study on the durability impact of concrete by using recycled waste water", Journal of industrial pollution control, 2008, Page No. 1-8.

\section{AUTHORS PROFILE}

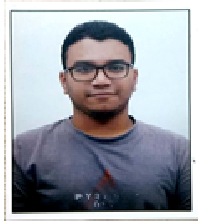

Mr. Mayuresh S. Bajbalkar, Final year Civil Engineering student, Pimpri Chinchwad College of Engineering, Nigdi, Pune.



Mr. Rushikesh R. Bangar, Final year Civil Engineering student, Pimpri Chinchwad College of Engineering, Nigdi, Pune.

Mr. Pratik D. Pawar, Final year Civil Engineering student, Pimpri Chinchwad College of Engineering, Nigdi, Pune.

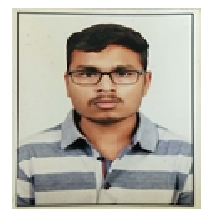

Mr. Rahul S. Chaudhari, Assistant Professor, Civil Engineering Department, Pimpri Chinchwad College of Engineering, Nigdi, Pune. Area of Interest: Construction Management.

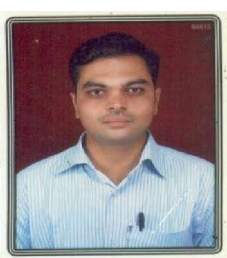
Memberships: ISTE, IWWA, IEI, QCFI Achievements: University Topper in Construction Management 